\title{
Palaeozoic granites and their younger components - A study of Mandi and Rakcham granites from the Himachal Himalaya
}

\author{
A Kundu*, NC Pant and Sonalika Joshi \\ Geological Survey of India, NH-5P, NIT Faridabad-121001, Haryana, INDIA \\ * For correspondence, email: akundu62@rediffmail.com
}

Several occurrences of Palaeozoic granites are recorded from the Lesser Himalayas as well as from the Higher Himalayas (Miller et al. 2001). From Himachal many such bodies have been dated (Bhanot et al. 1979, Frank et al. 1977, Jager et al. 1971, Kwatra et al. 1986, Pognante et al. 1990, Kwatra et al. 1999, Kundu et al. 2006). All of these bodies are deformed and several occur in the vicinity of Main Central Thrust (MCT). Studies have indicated presence of more than one granite type in most of these occurrences (e.g. Gupta 1974, Chatterjee 1976) but definitive reference to the Himalayan orogeny has generally been lacking. The present work supplements the earlier field and petrographic classification with rigorous mineralogical including rare earth element (REE) bearing mineral data for the two Paleozoic granites of Mandi and Rakcham and show association of younger granites with these occurrences.

Four petrographic variants of Mandi granites can be identified (Chatterjee 1976). These are as follows.

1. Porphyritic granite: With two mica and two feldspar. The ratio of the micas number to feldspar phenocryst vary. The other mineral phases are quartz, ilmenite, sphene, epidote, zircon, secondary muscovite, chlorite, monazite, allanite, zircon, apatite and fluorite.

2. Fine grained porphyritic granite: Two mica two feldspar granite and mineralogy similar to the porphyritic granite but has distinctly finer ground mass size and less phenocrysts.

3. Trondjhemite/albite granite: Leucocratic rock with one feldspar (albite) and one mica (muscovite). Other minerals are quartz, rare biotite, chlorite, wolframite, iron oxides, monazite, fluorite, apatite and tourmaline.

4. Leucogranite/tourmaline granite: Two feldspar and one mica (muscovite) granite, some outcrops have significant amount of tourmaline (more than 1\%). Quartz, k-feldspar, albite, tourmaline, muscovite, fluorite, monazite etc. In Rakcham occurrence three variants are identifiable namely 1. porpyritic granite: two feldspar biotite granite, 2 . granodiorite and 3 . trondjhemite. The latter two variants are subordinate and the major constituent is the porphyritic granite. Magma mingling is indicated by the presence of mafic pillows in the Mandi occurrence (Miller et al. 2001).

Mandi Occurrence: In porphyritic granite plagioclase has a range of composition. The larger grains of plagioclase are zoned with core composition (An29) being more calcic than the rim (An23). Finer grained matrix grains are less calcic (An12) and inclusion of plagioclase within K-feldspar is nearly pure albite. Biotite has a high Fe content $(\mathrm{Fe} / \mathrm{Fe}+\mathrm{Mg} \sim 0.73)$. The fine grained porphyritic granite has nearly albitic plagioclase and the biotite is more $\mathrm{Fe}$ rich $(\mathrm{Fe} / \mathrm{Fe}+\mathrm{Mg} \sim 0.780)$. In trondjhemitic granite the albite is the main feldspar and muscovite is the only mica present. The iron content of the muscovite in this variant is over 3 times that of the same mineral in other varmints of Mandi occurrence. Enclaves present in the Mandi occurrence include enclaves of host rock (schist) engulfed by the granite during ascent, mica-rich coarse grained small rounded to oval lumps of restite material, fine grained, melanocratic commonly angular small sized dioritic rocks and oval to elongated, pillow shaped, melanocratic, up to 5 $\mathrm{m}$ in size mafic rocks (basalts). In diorite biotite as phenocrysts are more magnesium $(\mathrm{Fe} / \mathrm{Fe}+\mathrm{Mg} \sim 38)$ than those in the groundmass $(\mathrm{Fe} / \mathrm{Fe}+\mathrm{Mg} \sim 48)$. Anorthite content of plagioclase is $\sim$ An37. In contrast the mafic rock has higher $\mathrm{Ca}$ in plagioclase (An70) and lower Fe in biotite $(\mathrm{Fe} / \mathrm{Fe}+\mathrm{Mg} \sim 18)$. Most Fe rich composition of biotite in enclaves is observed in restite $(\mathrm{Fe} / \mathrm{Fe}+\mathrm{Mg} \sim 72)$, while the plagioclase in this is most albitic (An18).

Rakcham Occurrence: In porphyritic granite perthitic Kfeldspar is the dominant mineral while plagioclase is relatively finer grained and subordinate. Biotite is the main mafic mineral. Muscovite is of two generations. Composition of the host in perthitic K-Feldspar has significant $\mathrm{Na}$ content ( $\mathrm{Ab} \sim 8 \%)$. Anorthite content of plagioclase varies from oligoclase to andesine. Plagioclase is locally zoned in granodiorite and has higher calcium (An44), biotite is the main mafic and the muscovite content is very low. Garnet and alanite is present occasionally. Trondjhemite is relatively finer grained variant and is made up dominantly of quartz, plagioclase and muscovite with rare biotite. Plagioclase is Ca-poor (albite to oligoclase). Monazite in the porphyritic granite from Rakcham is a Ce-monazite.

Chemical dating of both Mandi and Rakcham granite bodies has been carried out. In a euhedral monazite enclosed within quartz, chemical age determination yielded an age of $462 \mathrm{Ma}$ with a standard deviation of $44 \mathrm{Ma}$ (Kundu et al. 2006). This compares well with the reported $\mathrm{Rb} / \mathrm{Sr}$ age of $453 \pm 9 \mathrm{Ma}$ for the Akpa, a granite body possibly part of Rakcham granite and $477 \pm 29 \mathrm{Ma}$ for Rakcham (Kwatra et al. 1999). Indications of Teritiary ages is obtained from two samples in the Rakcham area thus describing coexistence of Himalayan granite in this Pan-African age granite complex. In Mandi, the dominant granite (porphyritic granite) gives Pan-African age (514 Ma with a standard deviation of $49 \mathrm{Ma}$ ), which compares well with the reported age data for this occurrence (Jager et al. 1971, Mehta, 1977, Miller et al. 2001). However, effects of resetting of ages of monazite and commensurate mineralogical transformations record imprints of Tertiary geological events. It is possible that besides the presence of Tertiary granite, formation of trondjhemite may also be linked to the Himalayan mountain building processes in Mandi and Rakcham occurrences. 
References

Bhanot VB, AK Bhandari, VPSingh and AKKansal. 1979. Geochronological and geological studies of granites of Higher Himalaya, NE of Manikaran, H. P. Journal of the Geological Society of India 20: 90-94

Chatterjee BC. 1976. Petrology and structural geology of the Mandi granite, Mandi district, Himachal Pradesh. Geological Survey of India Miscellaneous Publications 24: 302-315

Frank W, A Gansser and V Trommsdorff. 1977. Geological observations in the Ladakh area (Himalaya): a preliminary report. Schweizerische Mineralogische und Petrographische Mitteilungen 57: 89-113

Gupta LN. 1974. Petrology of Mandi granites and associated rocks. Center of Advanced Studies, Punjab University, Chandigarh 10: 95-108

Jager E, AK Bhandari and VB Bhanot. 1971. Rb-Sr age determinations on Biotites and whole rock samples from the Mandi and Chor granites, Himachal Pradesh, India. Ecologae Geologica Helvetia 64(3): 521-527

Kwatra SK, VB Bhanot, RK Kakar and AK Kansal. 1986. Rb-Sr radiometric ages of the Wangtu Gneissic complex , Kinnaur District, Higher Himachal Himalayas. Bulletin Indian Geological Association 19(2): 127-130

Kwatra SK, S Singh, VP Singh, RK Sharma, B Rai and N Kishore. 1999. Geochemical and geochronological characteristics of the early Palaeozoic granitoids from Sutlej-Baspa Valleys, Himachal Himalayas. In: Jain AK and RM Manickavasagam(eds). Geodynamics of the N-W Himalaya. Gondwana Research Group Memoir No.6: 145-158

Kundu A, S Joshi, NC Pant and D Bhatnagar. 2006. Electron microprobe dating technique- critical evaluation and application for a PanAfrican granite from the Himachal Himalayas. Indian Journal of Geochemistry 21(1): 211-230

Mehta PK. 1977. Rb-Sr geochronology of the Kulu-Mandi belt: its implication for the Himalayan tectonogenesis. Geologische Rundschau 66(1): 156-175

Miller C, M Thoni, W Frank, B Graseman, T Klotzli, D Guntli and E Draganits. 2001. The early Palaeozoic magmatic event in the Northwest Himalaya, India: Source, tectonic setting and age of emplacement. Geological Magazine 138(3): 237-251

Pognante U, D Castelli, P Benna, G Genovese, F Oberali, M Meier and Tonarini S. 1990. The crystalline units of the high Himalayas in the Lahaul-Zanskar region (northwest India): Metamorphic-tectonic history and geochronology of the collided and imbricated Indian plate. Geological Magazine 127: 101-116 